\title{
AGRONOMIC CHARACTERIZATION AND RESISTANCE OF BANANA GENOTYPES TO Colletotrichum musae
}

\author{
CARACTERIZAÇÃO AGRONÔMICA E RESISTÊNCIA GENÓTIPOS DE BANANA A \\ Colletotrichum Musae
}

\author{
Marcio Akio OOTANI ${ }^{1}$; Gil Rodrigues dos SANTOS $^{2}$; Gabriela Priscila de Sousa MACIEL ${ }^{3}$; \\ Clovis Maurilio de SOUZA ${ }^{4}$; Raimundo Wagner de Souza AGUIAR ${ }^{5}$; \\ Ingrid Bernardo de Lima COUTINHO ${ }^{6}$ \\ 1. Doutor em Agronomia/Fitotecnia Universidade Federal do Ceara - UFC, Fortaleza, CE, Brasil, ootani667@uft.edu.br; \\ 2. Professor, Doutor, Departamento de Fitopatologia Universidade Federal do Tocantins - UFT, Gurupi, TO, Brasil; \\ 3. Graduanda em Agronomia Universidade Federal do Ceara - UFC, Fortaleza, CE, Brasil; 4. Professor, Doutor, \\ Departamento de Fruticultura Universidade Federal do Tocantins - UFT, Gurupi, TO, Brasil; 5. Professor, Doutor, \\ Departamento de Biologia Molecular Universidade Federal do Tocantins - UFT, Gurupi, TO, Brasil; 6. Doutora em \\ Agronomia/Fitotecnia Universidade Federal do Ceara - UFC, Fortaleza, CE, Brasil,
}

\begin{abstract}
Banana is the most consumed fruit in the world as it is a delicious and aromatic fruit. However, its production is limited mainly due post-harvest problems such as diseases, especially anthracnose, which accelerates senescence and causes early fall. The aim of this work was to evaluate the agronomic traits and the resistance of banana genotypes (Fhia 18, Fhia 01, Thap Mae, Caipira, Prata (control) and Maçã (control)) to the fungus Colletotrichum musae. The weight of bunch $(\mathrm{Wb})$, fruit length $(\mathrm{Fl})$, fruit diameter $(\mathrm{Fd})$, the number of fruits per bunch $(\mathrm{Nfc})$, number of hands per bunch (Nhb), yield (Yd), pH, total sugars (Brix) and finger detachment were evaluated. The AUDPC (area under the disease progress curve) showed that the genotypes Fhia 01, Maçã and Prata (15.77, 15.55 and 11.60 respectively) are more susceptible to the fungus $C$. musae than Caipira, Fhia 18 and Thap maeo (6.66, 7.29 and 8.76 respectively). The experiment with Fhias 18 and Thap Maeo genotypes showed lower finger detachment of 18 and 15\%, and Thap maeo, Fhia18 and Caipira were resistant to $C$ musae and presented the best agronomic characteristics.
\end{abstract}

KEYWORDS: Anthracnose. Finger detachment. Post-Harvest.

\section{INTRODUCTION}

Banana is the second most produced fruit in the world, with a consumption of around 37.8 kilograms/person/year. Brazil is the fourth world producer with a production of 7.02 million tons/year (IBGE, 2015), being only behind India which produces 29.7, China with 9.84 and Ecuador with 7.93 million tons (FAO, 2012).

Diseases are the most limiting factors that affect the banana crop, and they can reduce yield and cause several socioeconomic impacts (ALVINDIA, 2013). Regarding these diseases, it is important to emphasize the post-harvest ones. They are a threat to food safety due to the introduction of mycotoxins which can affect the fruit flavor. Postharvest fungi are capable of causing losses superior to $40 \%$ in infected banana bunches, and the main causing agents are Lasiodiplodia theobromae (ALVINDIA, 2008), Colletotrichum musae (PESSOA et al., 2007), Thielaviopsis paradoxa (ALVINDIA, 2012) and Fusarium spp. (PRUSKY, 2010; ALVINDIA, 2012).

Some studies relate banana resistance to postharvest diseases (CHILLET et al., 2009). However, trials have shown that some commercial varieties were tolerant to these post-harvest diseases (CHILLET et al., 2009). Among these varieties, there are the hybrids (AAAB) Pioneer, PV03-44, Fhia-01, SH3640 and Fhia-18 and Caipira (AAA), Thap Maeo (AAA) and Prata anã (AAB), Maçã (AAAB) (CORDEIRO; MATOS, 2005).

Some genotypes are more relevant, such as Maçã, Mysore, cultivars from the Prata subgroup (Prata, Pacovan and Prata anã), plátano (D'angola), and Cavendish group (Nanica, Nanicão e Grande Naine). Prata represents $60 \%$ of the cultivated area of banana in Brazil (CARVALHO et al., 2011). Nevertheless, even with the great importance and representativeness of these genotypes, they are all susceptible to the major diseases. These diseases can affect banana crops, causing production losses up to $100 \%$ depending on the agricultural techniques and the environmental conditions (COOK et al., 2015).

The replacement of a traditionally explored variety in one or several regions in the world is hard because the banana market is demanding. Besides, in most cases, the new introductions do not maintain some organoleptic properties such as flavor (PIMENTEL et al., 2010). Finger detachment and natural fall of the fruit restrict the durability (MAIA et al., 2004). This phenomenon occurs because of 
the physiological weakening at pedicel which leads to the individual separation of the fruits from the bunch (AMORIM et al., 2012).

Banana is the most cultivated fruit in the state of Tocantins, and it is crucial for the economy, especially to small and medium producers. It has also a social importance because it generates jobs, maintaining men in the countryside.

Thus, the aim of this study was to evaluate post-harvest agronomic characteristics of several banana genotypes which are cultivated in the state of Tocantins and to assess their resistance to the fungus Colletotrichum musae.

\section{MATERIALS AND METHODS}

The experiments were performed from 2008 to 2009 at the Phytopathology Laboratory at the Federal University of Tocantins, Gurupi.

Fruits were obtained at Serrinha production center and in the experimental field of the Federal University of Tocantins. The agronomic assessments of the genotypes Fhia 18, Fhia 01, Thap Maeo, Caipira, Prata (control) and Maçã (control) were made using the methodology adopted by Pereira et al. (2003), evaluating the weight of bunches $(\mathrm{Wb})$, fruit length $(\mathrm{Fl})$, fruit diameter $(\mathrm{Fd})$, in centimeters, number of fruits per bunch $(\mathrm{Nfb})$ and number of hands per bunch (Nhb). Evaluations were performed in the second cycle from October to March 2007-2008 and 2008-2009, in daughters plants, with seven replicates. A manual refractometer was used to measure the degree of Brix and sugar quantification in ripe fruits, and a $\mathrm{pH}$ meter was used to measure the $\mathrm{pH}$, according to the methodology employed by Dadzie; Orchard (2001).

The experiment was performed in a completely randomized design (CRD), and data, not including finger detachment, were submitted to analysis of variance (ANOVA) with means compared by the Tukey test at 5\% probability, using the statistical program SISVAR 5.8 (FERREIRA, 2011).

For the finger detachment, three replicates with ten bananas of each genotype hanging under gravity in a room at $24^{\circ} \mathrm{C}$ were used. They were analyzed daily to determine the percentage of finger detachment. The genotypes were evaluated based on the finger detachment rate, where $0-25 \%$ represented low susceptibility; 26-50\% medium susceptibility; $51-75 \%$ high susceptibility, and 76$100 \%$ very high susceptibility to finger detachment (DADZIE; ORCHARD, 2001).
The fungus was obtained from a mycology collection (strain COLL001) at the Phytopathology Laboratory at the Federal University of Tocantins. A test to verify the pathogenicity of $C$. musae was performed, and the fungi were preserved in Castelani glasses containing sterile water, and they were inoculated in bananas. As the symptoms appeared, isolation and pricking to Petri dishes containing PDA (Potato, Dextrose and Agar) medium were performed. Then, after seven days, a monosporic colony was obtained, and it was used in the experiments.

The bunches of each genotype were collected in the pre-climacteric stage of twenty-four months, were sanitized with hypochlorite $1.5 \%$ during two minutes, alcohol $70 \%$ during thirty seconds, and then they were washed with distilled water, dried in shadow and packaged in plastic trays. The experiment was performed in a completely randomized design, with seven genotypes containing four replicates, and each replicate contained ten fruits packaged in plastic covered boxes. Each fruit was inoculated with a mycelium disk (6 $\mathrm{mm}$ diameter), and a drilling was performed with a small stylus $(1 \mathrm{~mm})$ at the insertion under the mycelium disk.

The boxes containing the fruits were placed in an incubation chamber at $27^{\circ} \mathrm{C}$, relative humidity of $80 \%$ during a photoperiod of twelve hours. The evaluation was conducted daily using a digital caliper rule. Data were analyzed by regression using the program Sigma plot 11. Parameters such as the area under the disease progress curve (AUDPC) (IRFAQ et al. 2009) were evaluated. ANOVA and the means were compared by the Tukey test at $5 \%$ probability using the program SISVAR 5.8 (FERREIRA, 2011). The AUDPC was calculated according to the formula:

$$
\mathrm{AUDPC}=\sum_{i}^{n-1}\left(\frac{y_{i}-y_{i-1}}{2}\right)\left(T_{i+1}-T_{i}\right)
$$

AUDPC: Area Under the Disease Progress

Curve time $\mathrm{T}$;

$Y_{i:}$ proportion of mycelial growth halo at

$\mathrm{Y}_{\mathrm{i}-1}$ : initial of mycelial growth halo in the fruit;

$\mathrm{T}_{\mathrm{i}+1}$ : Mycelial growth halo time;

$\mathrm{T}_{\mathrm{i}}$ : Initial time of mycelial growth;

\section{RESULTS AND DISCUSSIONS}

According to Fehlauer et al. (2010), the genotypes Fhia 1 and Fhia 18 had higher bunch weight, and larger fruit length in the Cerrado biome 
in the state of Mato Grosso do Sul, with a yield of 26.95 and 24.5 ton/ha respectively, being more productive than Prata-Anã and Caipira for Conditions of the cerrado of Tocantins, but they were statistically inferior to the Thap Maeo genotype

Thap Maeo genotype showed the greatest number of fruits, with an average of 215.6 fruits and yield of 27.25 ton. Thus, the number of bunches and yield were high when compared to the other genotypes (Table 10). Regarding fruits length, the hybrids Fhia 1, Fhia 18 and Prata were significantly superior; in practice, this has been a significant determining factor to the final yield of these varieties, since the fruits diameter did not change among the genotypes (Table 1) and considering that the first two genotypes are more productive compared to Prata, according to Fehlauer et al. (2010)

Table 1. Agronomic traits: Weight of bunches $(\mathrm{Wb})$, the number of fruits per bunch $(\mathrm{Nfb})$, number of hands per bunch $(\mathrm{Nhb})$, fruit length $(\mathrm{Fl})$, fruits diameter $(\mathrm{Fd})$ and yield $(\mathrm{Yd})$ of six banana genotypes.

\begin{tabular}{lcccccc} 
Genotypes & $\mathrm{Wb}(\mathrm{Kg})^{*}$ & $\mathrm{Nfb}(\mathrm{un})^{*}$ & $\mathrm{Nhb}(\mathrm{un})^{*}$ & $\mathrm{Fl}(\mathrm{cm})^{*}$ & $\mathrm{Fd}(\mathrm{cm})^{*}$ & $\mathrm{Yd}(\mathrm{ton} / \mathrm{ha})$ \\
\hline Fhia 01 & $10.41 \mathrm{bc}$ & $73.10 \mathrm{~b}$ & $6.66 \mathrm{a}$ & $15.00 \mathrm{a}$ & $3.40 \mathrm{a}$ & $25.85 \mathrm{a}$ \\
Fhia 18 & $13.75 \mathrm{abc}$ & $113.76 \mathrm{~b}$ & $7.86 \mathrm{a}$ & $15.16 \mathrm{a}$ & $2.96 \mathrm{a}$ & $24.92 \mathrm{a}$ \\
& & & & & & \\
Prata & $15.00 \mathrm{ab}$ & $109.00 \mathrm{~b}$ & $7.10 \mathrm{a}$ & $15.00 \mathrm{a}$ & $2.80 \mathrm{a}$ & $12.55 \mathrm{~b}$ \\
Thap Maeo & $16.30 \mathrm{ab}$ & $215.66 \mathrm{a}$ & $9.66 \mathrm{a}$ & $10.50 \mathrm{~b}$ & $3.03 \mathrm{a}$ & $27.25 \mathrm{a}$ \\
Caipira & $7.68 \mathrm{c}$ & $117.16 \mathrm{~b}$ & $7.00 \mathrm{a}$ & $9.26 \mathrm{~b}$ & $2.56 \mathrm{a}$ & $15.50 \mathrm{~b}$ \\
Maçã & $8.00 \mathrm{c}$ & $110.00 \mathrm{~b}$ & $7.50 \mathrm{a}$ & $10.00 \mathrm{~b}$ & $2.90 \mathrm{a}$ & $15.47 \mathrm{~b}$ \\
\hline Means & 13.27 & 120.76 & 7.65 & 12.84 & 2.99 & 20.30 \\
CV (\%) & 22.48 & 15.98 & 19.26 & 8.50 & 10.47 & 8.94
\end{tabular}

*Means with the same letter do not differ statistically by the Tukey test $(\mathrm{p}<0.05)$.

The decrease in acidity is influenced by the use of organic acids for ATP production. Moreover, the respiration process produces organic acids, which may cause a slight increase in acidity (PIMENTEL et al., 2010).

Genotype Fhia 01 was considered the less acid, while Fhia 18 represented the most acid fruits, being below 5.0 on the $\mathrm{pH}$ scale. Thap Maeo and Caipira were in an intermediate position, with the commercial cultivar Prata. There was no significance in the comparison performed by Tukey test at $5 \%$ probability (Table 2 ).

Finger detachment is considered a natural detachment of the ripe fruit. It is a result of the individual separation of the crown from the fruit bunch; it is an undesirable characteristic for the market. The fruit that has undergone detachment has a reduced shelf life, and it does not have a good appearance (HAILU et al., 2014). Fhia 18 and Thap Maeo were far superior presenting $18 \%$ and $15 \%$ respectively. Except for Fhia 01, all genotypes tested in this trial offer a great market potential, regarding this undesirable feature, being better than commercial genotypes that are widely accepted in the domestic market, such as Prata and Maçã (Table 2). 
Table 2. Organoleptic properties (Brix and $\mathrm{pH})$, finger detachment percentage $(\mathrm{FdP})$ and finger detachment (Fd) of six banana genotypes.

\begin{tabular}{lllll}
\hline Genotypes & Brix* & $\mathrm{pH}^{*}$ & $\mathrm{FdP}(\%)$ & $\mathrm{Fd}$ \\
\hline Fhia 01 & $12.60 \mathrm{a}$ & $5.74 \mathrm{a}$ & 78 & Very high susceptibility \\
Fhia 18 & $12.48 \mathrm{a}$ & $4.74 \mathrm{~d}$ & 18 & Low susceptibility \\
Thap Mae & $11.88 \mathrm{a}$ & $5.21 \mathrm{~b}$ & 15 & Low susceptibility \\
Caipira & $11.70 \mathrm{a}$ & $5.17 \mathrm{bc}$ & 41 & Medium susceptibility \\
Prata & $11.46 \mathrm{a}$ & $5.04 \mathrm{c}$ & 72 & High susceptibility \\
Maçã & $11.30 \mathrm{a}$ & $5.53 \mathrm{~b}$ & 63 & High susceptibility \\
\hline Means & 11.87 & 5.14 & & \\
CV $(\%)$ & 15.80 & 1.47 & & \\
\hline *Means with the same letter do not differ statistically by the Tukey test $(\mathrm{p}<0.05)$. &
\end{tabular}

In the anthracnose resistance experiment comparing the six banana genotypes, three genotypes were not statistically significant for AUDPC and Thap maeo, Fhia 18 and Caipira were statistically superior to the other genotypes (Table 3 and Figure 1). Anthracnose is a disease that can become dormant on the surface of the fruit during the immature stage. With the progressive maturation of the fruit, the spores germinate and cause a stain on the surface, which can depreciate the appearance, damaging the sale of these fruits.

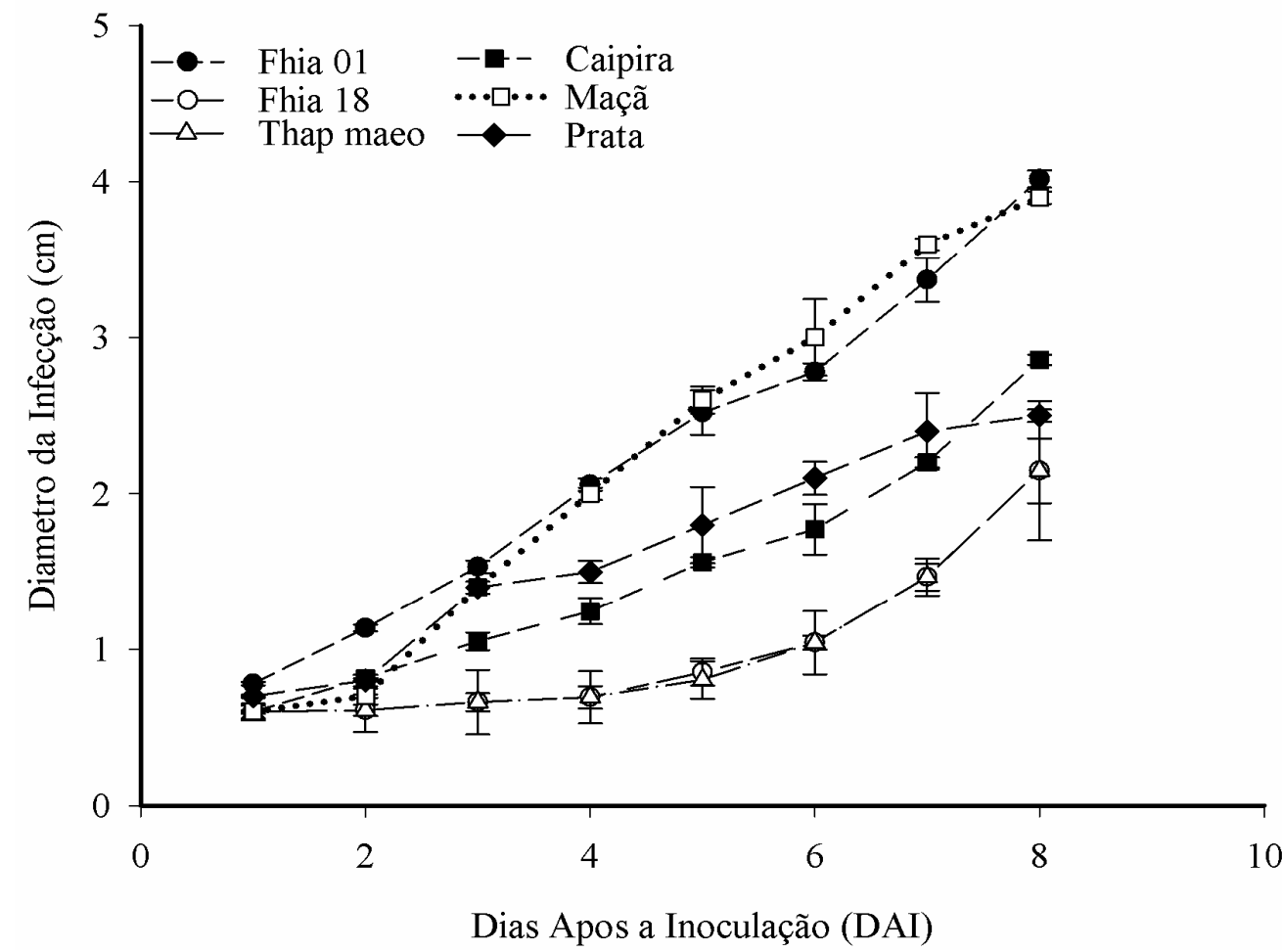

Figure 1. Mycelia growth in vivo of Colletotrichum musae over time with standard bar error.

For AUDPC it was shown that the disease progression and the speed were higher in the genotypes mentioned above since they are more susceptible to the fungus $C$. musae. On the other hand, the genotypes Caipira, Thap maeo and Fhia 18 presented resistance to the fungus, and consequently, a longer shelf life. This is because anthracnose fungus caused by Colletotrichum musae interferes mainly in the marketing of fruits. The physiological age is what determines susceptibility to anthracnose according to Chillet et al. (2007), who observed that the diameter of the necrotic area in banana was greater in those with higher physiological age. 
Table 3. Parameter equation of the quadratic regression analysis of the diameter of the infection with C. musae post-harvest fungus.

\begin{tabular}{llllll}
\hline Genotypes & Equation & $\mathrm{F}_{\text {Regression }}$ & $\mathrm{P}$ & $\mathrm{R}^{2}$ & AUDPC* \\
\hline Fhia 01 & $\mathrm{Y}=0.001 \mathrm{x}^{2}+0.331 \mathrm{x}+0.438$ & 551.94 & $<0.0001$ & $0.99^{* *}$ & $15.77 \mathrm{a}$ \\
Fhia 18 & $\mathrm{Y}=0.037 \mathrm{x}^{2}+0.103 \mathrm{x}+0.580$ & 88.19 & 0.0001 & $0.96^{* *}$ & $7.29 \mathrm{c}$ \\
Thap Mae & $\mathrm{Y}=0.051 \mathrm{x}^{2}-0.271 \mathrm{x}+0.903$ & 105.43 & $<0.0001$ & $0.96^{* *}$ & $8.76 \mathrm{bc}$ \\
Caipira & $\mathrm{Y}=0.050 \mathrm{x}^{2}-0.250 \mathrm{x}+0.885$ & 108.88 & $<0.0001$ & $0.96^{* *}$ & $6.66 \mathrm{c}$ \\
Prata & $\mathrm{Y}=-0.008 \mathrm{x}^{2}+0.348 \mathrm{x}+0.292$ & 132.34 & $<0.0001$ & $0.97 * *$ & $11.60 \mathrm{~b}$ \\
Maçã & $\mathrm{Y}=-0.002 \mathrm{x}^{2}+0.533 \mathrm{x}-0.114$ & 214.81 & $<0.0001$ & $0.98^{* *}$ & $15.55 \mathrm{a}$ \\
\hline Mean & ----- & ----- & ----- & ----- & 10.46 \\
CV\% & ----- & ---- & ---- & ----- & 10.45 \\
\hline
\end{tabular}

*Means with the same letter do not differ statistically by the Tukey test $(\mathrm{p} \leq 0.05)$; AUDPC $=$ Area under the disease progress curve

For the bioassay in vivo of the post-harvest fungus $C$. musae, the largest slopes of the regression were for Fhia 01, Prata and Maçã (0.331, 0.348 and 0.533 ) indicating high sensitivity to Colletotrichum musae being significant at $5 \%$ probability. On the other hand, the genotypes Caipira, Thap maeo and Fhia 18 presented greater resistance to the fungus, and consequently, a superior shelf life. Studies performed by Pinho et al. (2010) demonstrated that the genotype Thap Maeo showed less severity (27.5\%) to anthracnose, while the genotypes Fhia 18 was the most susceptible, with $61.33 \%$ severity levels. Studies by several authors have shown the importance of the exploitation of these genotypes mainly because they are resistant to Mycosphaerella fijiensis (PINHO et al., 2010).

\section{CONCLUSIONS}

Fhia 18, Caipira and Thap maeo were more resistant to $C$. musae when compared to the commercial genotypes Prata e Maçã and with the best agronomic traits.

RESUMO: A banana é fruta mais consumida no mundo, tradicionalmente exploradas em várias regiões do mundo, pois é uma fruta de muito saborosa e aromática. Contudo sua produção é limitada principalmente por problemas pós-colheita que mais acometem o fruto, dentre elas aparecimento de doenças principalmente a antracnose que acelera a senescência e o despencamento precoce. O objetivo desde trabalho foram avaliadas as características agronômicas e a resistência dos genótipos de banana Fhia 18, Fhia 01, Thap Mae, Caipira, Prata (controle) e Maçã (Controle), ao fungo Colletotrichum musae. A avaliação das características agronômicas como; peso do cacho (PC), comprimento dos frutos (CF), diâmetro do fruto (DF), número de frutos por cacho (NFC), número de pencas por cacho (NPC), Produtividade (Pd), $\mathrm{pH}$, açúcares totais (Brix) e despencamento. A AACPD Área abaixo da curva da progressão da doença nos genótipos Fhia 01, Maçã e Prata $(15,77,15,55$ e 11,60 respectivamente) mostraram se mais suscetível ao fungo $C$. musae que os demais genótipos Caipira, Fhia 18 e Thap maeo (6,66, 7,29 e 8,76 respectivamente), enquanto que para o experimento de despencamento genótipos Fhias 18 e Thap Maeo foram os que tiveram menor despencamento 18 e $15 \%$, e a Os genótipos Thap maeo Fhia18 e Caipira foram resistentes a $C$ musae e tiveram as melhores características agronômicas.

PALAVRAS-CHAVE: Antracnose. Despencamento. Pós-colheita.

\section{REFERENCES}

ALVINDIA, D. G. Improving control of crown rot disease and quality of pesticide-free banana fruit by combining Bacillus amyloliquefaciens DGA14 and hot water treatment. European Journal of Plant Pathology, v. 136, n. 1, p. 183-191, 2013. https://doi.org/10.1007/s10658-012-0154-7

ALVINDIA, D. G. Revisiting hot water treatments in controlling crown rot of banana cv. Buñgulan. Crop Protection, v. 33, p. 59-64, 2012. https://doi.org/10.1016/j.cropro.2011.09.023

ALVINDIA, D. G.; NATSUAKI, K. T. Evaluation of fungal epiphytes isolated from banana fruit surfaces for biocontrol of banana crown rot disease. Crop Protection, v. 27 p. 1200-1207, 2008.

https://doi.org/10.1016/j.cropro.2008.02.007 
AMORIM, E. P.; PESTANA, R. K. N.; SILVA, S. D. E.; NETO, A. T. Agronomic characterization of banana mutants obtained by gamma radiation. Bragantia, Campinas v. 71, n. 1, p. 8-14, Jan-Mar 2012. https://doi.org/10.1590/S0006-87052012005000002

CARVALHO, A. V.; SECCADIO, L. L.; JÚNIOR, M. M.; NASCIMENTO, W. M. O. Qualidade Pós-Colheita de Cultivares de Bananeira do Grupo 'Maçã', Na Região De Belém - PA. Revista Brasileira de Fruticultura, Jaboticabal, v. 33, n. 4, p. 1095-1102, 2011.

CHILLET, M.; ABADIE, C.; HUBERT, O.; CHILIN-CHARLES, Y.; DE LAPEYRE DE BELLAIRE, L. Sigatoka disease reduces the greenlife of bananas. Crop Protection, v. 28, n. 2, p. 41-45, 2009. https://doi.org/10.1016/j.cropro.2008.08.008

CHILLET, M.; HUBERT, O.; BELLAIRE, L. L. Relationship between physiological age, ripening and susceptibility of banana to wound anthracnose. Crop Protection, v. 26, n. 7, p. 1078-1082, 2007. https://doi.org/10.1016/j.cropro.2006.09.012

COOK, D. C.; TAYLOR, A. S.; MELDRUM, R. A.; DRENTH, A. Potential economic impact of Panama disease (tropical race 4) on the Australian banana industry. Journal of Plant Diseases and Protection, v. 122, n. 5-6, p. 229-237, Dec 2015. https://doi.org/10.1007/BF03356557

CORDEIRO, Z. L. M; MATOS, A. P. de. Expressão da Resistência de Variedades de Banana à SigatokaAmarela. Fitopatologia Brasileira, Viçosa, v. 30, n. 5, p. 532-534, 2005.

DADZIE, B. K.; ORCHARD, J. E. Routine post-harvest screening of banana/plantain hybrids: criteria and methods. In: INIBAP Technical Guidelines. France: CIRPAC, 2001. 75p.

FAOSTAT (Food and Agriculture Organization Of The United Nations). Disponível em: http://faostat.fao.org/site/567/> Acesso em: 18/04/2015.

FEHLAUER, T. J.; RODRIGUES-OTUBO, B. M.; SANDRINI, M.; DESTRO, D. Caracterização da produção de genótipos de banana introduzidos na região de Bonito -MS. Revista Brasileira Fruticultura, Jaboticabal, v. 32, n. 3, p. 938-943, 2010.

FERREIRA, D. F. Sisvar: a computer statistical analysis system. Ciência e Agrotecnologia, Lavras, v. 35, n. 6, p. 1039-1042, 2011.

HAILU, M.; SEYOUM WORKNEH, T.; BELEW, D. Effect of packaging materials on shelf life and quality of banana cultivars (Musa spp.). Journal Food Science Technology, v. 51, n. 11, p. 2947-63, Nov 2014. https://doi.org/10.1007/s13197-012-0826-5

IBGE (Instituto Brasileiro de Geografia e Estatística) LSPA (Levantamento Sistemático da Produção Agrícola). Rio de Janeiro, v.29 n.5 p.1-76, 2015.

IRFAQ, M.; AJAB, M.; MA, H.; KHATTAK, G. Assessment of genes controlling area under disease progress curve (AUDPC) for stripe rust ( $P$. striiformis $\mathrm{f}$. sp. tritici) in two wheat (Triticum aestivum L.) crosses. Tsitol Genet, v. 43, n. 4, p. 25-38, 2009. https://doi.org/10.3103/S0095452709040045

PESSOA, W. R. L. S.; DE OLIVEIRA, S. M. A.; DANTAS, S. A. F.; TAVARES, S. C. C. H.; SANTOS, A. M. G. Efeito da temperatura e período de molhamento sobre o desenvolvimento de lesões de Colletotrichum musae em banana. Summa Phytopathologica, Botucatu, v. 33, n. 2, p. 147-151, 2007.

PIMENTEL, R. M. D.; GUIMARAES, F. N.; DOS SANTOS, V. M.; DE RESENDE, J. C. F. Post-Harvest Quality of Genotypes of Banana 'Pa 42-44' and 'Prata Ana' Cultivated in the North of Minas Gerais. Revista Brasileira De Fruticultura, Jaboticabal, v. 32, n. 2, p. 407-413, Jun 2010. 
PINHO, D. B.; MIZOBUTSI, E. H.; E SILVA, S. O.; REIS, S. T.; MIZOBUTSI, G. P.; XAVIER A. A.; RIBEIRO, R. C. F.; MAIA, V. M. Avaliação de genótipos de bananeira à Colletotrichum musae em póscolheita. Revista Brasileira Fruticultura, Jaboticabal, v. 32, n. 3, p. 786-790, 2010.

PRUSKY, M. D.; GULlinO, L. Postharvest Pathology Plant Pathology in the 21st Century: Contributions to the 9th International Congress. Springer. 2010. p. 212. 